\title{
Precision of Hard Structures Used to Estimate Age of Riverine Catostomids and Cyprinids in the Upper Colorado River Basin
}

\author{
Michael C. Quist* AND Zachary J. Jackson \\ Department of Natural Resource Ecology and Management, \\ Iowa State University, 339 Science II, Ames, Iowa 50011, USA \\ Michael R. Bower \\ U.S. National Park Service, Post Office Box 579, Death Valley, California 92328, USA \\ Wayne A. Hubert \\ U.S. Geological Survey, Wyoming Cooperative Fish and Wildlife Research Unit, \\ University of Wyoming, Department 3166, 1000 East University Avenue, Laramie, Wyoming 82071, USA
}

\begin{abstract}
Understanding the population dynamics of native and nonnative fishes is critical for guiding and evaluating management activities, but obtaining information on population dynamics is often dependent on identifying structures that provide precise estimates of age. We examined age estimation using various hard structures for native bluehead suckers Catostomus discobolus, flannelmouth suckers C. latipinnis, and roundtail chub Gila robusta, and nonnative white suckers $C$. commersonii, creek chub Semotilus atromaculatus, white sucker $\times$ bluehead sucker hybrids, and white sucker $\times$ flannelmouth sucker hybrids in a small headwater stream of the upper Colorado River basin (UCRB) in Wyoming. We evaluated between-reader precision (i.e., between two readers) and agreement of otolith age estimates with estimates from scales, fin rays, cleithra, and opercular bones. Exact agreement between readers was highest for otoliths (66-96\% among species) and fin rays (61-92\%) and lowest for opercles (25-69\%), cleithra (21-41\%), and scales (15-48\%). Age estimates from fin rays were almost exactly the same as those from otoliths for all species except creek chub, for which fin ray estimates were consistently lower than otolith estimates. Age estimates from scales were generally 14 years lower than those from otoliths for most species, and most discrepancies occurred when otolith ages were greater than 5 years. We recommend that fin rays be used to estimate age of native catostomids and roundtail chub in the UCRB because fin rays provide accurate estimates of otolith age and can be obtained without sacrificing fish. We further recommend that otoliths be used to estimate age of creek chub in the UCRB because accuracy of fin rays was poor and because sacrificing this nonnative species may benefit native fishes of the UCRB
\end{abstract}

Fishes in streams and rivers are affected by a variety of physical, chemical, and biological factors; understanding how these factors influence fish populations is

\footnotetext{
* Corresponding author: mcquist@iastate.edu
}

Received June 26, 2006; accepted September 24, 2006 Published online May 3, 2007 important when assessing the status of native fishes. Native fishes in North America have been declining since the early 20th century due to extensive physicochemical and biological alterations of aquatic habitats (Williams et al. 1989; Moyle and Leidy 1992). Although species have declined across North America, the most widespread and substantial declines have occurred among species native to the Colorado River basin (Minckley and Deacon 1991). The Colorado River drainage encompasses approximately $16.9 \%$ of the land area of Wyoming and includes two major watersheds, the Little Snake and Green rivers. The native fish assemblage in the Colorado River drainage of Wyoming includes 11 species (Baxter and Stone 1995), six of which are considered warmwater riverine species: bluehead sucker Catostomus discobolus, flannelmouth sucker $C$. latipinnis, razorback sucker Xyrauchen texanus, roundtail chub Gila robusta, bonytail $G$. elegans, and Colorado pikeminnow Ptychocheilus lucius. Razorback suckers, bonytails, and Colorado pikeminnow are federally endangered species (Bezzerides and Bestgen 2002) and have been extirpated in Wyoming except in the Little Snake River, which contains Colorado pikeminnow at an exceedingly rare level. The Wyoming Natural Diversity Database describes the bluehead sucker and flannelmouth sucker as vulnerable to extinction and the roundtail chub as imperiled in Wyoming. The Wyoming Game and Fish Department identifies all three species as suffering ongoing significant losses of habitat and as having populations that are greatly restricted or declining and at risk for extirpation.

Information on age and growth is needed to gain insight into the ecology of native and nonnative fishes and to guide management decisions in the upper Colorado River basin (UCRB). Population assessments require an understanding of rate functions (i.e., growth, recruitment, mortality), but growth is particularly 
important (DeVries and Frie 1996). Similarly, knowledge of the age structure of populations provides insight on recruitment, population growth rates, and mortality.

Age of fishes can be estimated using a variety of hard structures, including scales, otoliths, fin rays, cleithra, and opercular bones (DeVries and Frie 1996). Some hard structures provide more accurate and precise estimates of age than others. For example, scales often underestimate ages of older fishes (e.g., Schramm and Doerzbacher 1985; Boxrucker 1986; Isermann et al. 2003), so other structures, such as otoliths or fin rays, are commonly used instead of scales (e.g., Erickson 1983). Selecting the proper structure for aging is critical for providing useful information to managers.

Hard structures have been used to age bluehead suckers (e.g., Scoppettone 1988), flannelmouth suckers (e.g., Scoppettone 1988), and roundtail chub (e.g., Vanicek and Kramer 1969; Brouder 2005), as well as other catostomids (e.g., Chen and Harvey 1995; Hoff et al. 1997; Peterson et al. 1999) and cyprinids (e.g., Quist and Guy 2001). Many of these studies have used otoliths, cleithra, or opercular bones to estimate age; these methods require not only a substantial amount of time to process but also the sacrifice of fish. Given the status of bluehead suckers, flannelmouth suckers, and roundtail chub in the UCRB, nonlethal methods for aging these species would be preferred over techniques that require lethal sampling of fish. Despite the importance of selecting the proper hard structures for examination, the precision among different structures and the utility of nonlethally obtained scales and fin rays for aging bluehead suckers, flannelmouth suckers, and roundtail chub are unknown. Our objective was to identify hard structures that provide precise estimates of age for native bluehead suckers, flannelmouth suckers, and roundtail chub and nonnative white suckers Catostomus commersonii, creek chub Semotilus atromaculatus, white sucker $\times$ bluehead sucker hybrids, and white sucker $\times$ flannelmouth sucker hybrids.

\section{Methods}

Fish were sampled from Muddy Creek in the Little Snake River drainage of the UCRB. This is one of two areas in Wyoming known to contain sympatric populations of bluehead suckers, flannelmouth suckers, and roundtail chub. The stream also contains nonnative white suckers that hybridize with native catostomids (Bower 2005) and creek chub that may compete with native roundtail chub (Quist et al. 2006). Portions of Muddy Creek containing these native and nonnative species generally have low channel gradients $(<1 \%)$ and substrate dominated by silt, sand, and gravel. Water temperatures vary from near freezing in winter to almost $23^{\circ} \mathrm{C}$ in summer (M.R.B., unpublished data). In addition, temperature fluctuations of $10^{\circ} \mathrm{C} / \mathrm{d}$ are common during summer months.

Catostomids were sampled in 2003 using electrofishing and seining, and roundtail chub and creek chub were sampled during 2004 using electrofishing. Fish were euthanatized and placed on ice for processing in the laboratory, where scales, pectoral fin rays, otoliths, opercle bones, and cleithra were obtained from all fish. Scales were collected from two areas of the body, including the area ventral to the lateral line and just posterior to the insertion of the pectoral fin (hereafter termed pectoral scales) and the area dorsal to the lateral line and just posterior to the dorsal fin (hereafter termed caudal scales). Scales were allowed to air dry in coin envelopes and then were pressed onto acetate slides ( $25.4 \mathrm{~mm}$ wide $\times 50.8 \mathrm{~mm}$ long $\times 1 \mathrm{~mm}$ thick). Scale impressions were read using a microfiche reader.

The marginal left pectoral fin ray was removed from each fish. The entire fin ray was removed by cutting at the junction of the fin ray and the body wall. Fin rays were allowed to dry in coin envelopes, were embedded in epoxy, and were sectioned (0.3-0.6 mm thick) using a Buehler Isomet Low-Speed Saw (Buehler, Lake Bluff, Illinois). Sectioned fin rays were examined using a stereoscope $(2-50 \times$ magnification) with transmitted light.

Otoliths were removed from each fish using the methods of Schneidervin and Hubert (1986). Sagittal otoliths from catostomids were easily broken during removal due to their small size and long, thin morphology. Therefore, we removed and used the asteriscus from all catostomids. Sagittal otoliths were removed from creek chub and roundtail chub. A subsample of 30 otoliths (approximately five from each species and hybrids) was processed following the techniques of Brouder (2005) and was compared with whole otoliths. Agreement between sectioned and whole otoliths was $100 \%$; therefore, whole otoliths were used to estimate age. Whole otoliths were viewed using transmitted light and a stereoscope.

The left opercle and left cleithrum were removed from all fish, placed in separate coin envelopes, stored in a freezer, and allowed to reach room temperature before processing. These structures were briefly (i.e., $<5 \mathrm{~s}$ ) immersed in boiling water, and tissue was removed from the bone using a plastic-bristled brush. Opercles and cleithra were allowed to air dry and were examined under a stereoscope using transmitted light.

Ages were estimated for all fish by two readers. Fish were aged without knowledge of age estimates from other structures or the other reader. Age-bias plots were used to assess between-reader precision for each structure (Campana et al. 1995). Plots were constructed 
for each structure by plotting the age estimates from reader 2 against estimates provided by reader 1 . Variation in age estimates between readers was assessed by calculating the percent agreement (i.e., exact agreement and within 1 year) in age estimates for each structure. The coefficient of variation (CV) in age estimates between readers was used as another measure of precision and was estimated as:

$$
\mathrm{CV}_{j}=100 \times\left\{\sum\left[\left(X_{i j}-X_{j}\right)^{2} /(R-1)\right]\right\}^{0.5} / X_{j}
$$

where $X_{i j}$ is the $i$ th age determination of the $j$ th fish, $X_{j}$ is the mean age of the $j$ th fish, and $R$ is the number of times each fish was aged (Campana et al. 1995). The $\mathrm{CV}$ was estimated for each individual fish and aging structure and then averaged across individuals to provide an estimate of between-reader precision by aging structure.

Accuracy of otoliths for aging the study species has been validated for roundtail chub by examining otoliths of known-age fish (Brouder 2005); however, otoliths are known to provide accurate age estimates across a diversity of species (e.g., Taubert and Tranquilli 1982; Erickson 1983; Parrish et al. 1994; Ross et al. 2005). As such, otolith ages were used as the standard with which other structures were compared. Agreement was estimated for each reader as the percent difference between the otolith age and the age estimated from the other structures. We also compared agreement between pectoral and caudal scales. A paired $t$-test was used to estimate whether age estimates from otoliths differed from age estimates obtained from other hard structures and whether age estimates from pectoral and caudal scales differed (Campana et al. 1995). Because multiple tests were conducted, a Bonferroni adjustment was used to determine statistical significance (Manly et al. 2002). Specifically, differences were not considered significant unless the $P$-value of the $t$-test was less than $\alpha / k$, where $k$ was the number of comparisons ( $k=36$ per reader) and $\alpha$ was the type I error rate (i.e., $\alpha=0.05$ ).

\section{Results}

We aged 256 fishes varying from 60 to $405 \mathrm{~mm}$ in total length (Table 1). Agreement in age estimates between readers varied by species and aging structure (Table 2). Exact agreement between readers was highest for otoliths and fin rays and lowest for opercles, cleithra, and scales. Most between-reader disagreements were within 1 year for otoliths, fin rays, cleithra, and opercles. Similar to percent agreement, otoliths and fin rays had the lowest mean between-reader CVs. When otoliths and fin rays were compared, otolith age estimates had the lowest between-reader $\mathrm{CV}$ for
TABLE 1.-Species, sample size $(N)$, and total length statistics of fish sampled for age estimation from Muddy Creek, Wyoming, in 2003-2005. Standard deviation (SD), minimum ( $\min$ ), and maximum ( $\max$ ) lengths are provided as an indication of the variation in fish lengths. Species were bluehead sucker (BHS), flannelmouth sucker (FMS), white sucker (WHS), hybrid catostomids (hybrid), creek chub (CKC), and roundtail chub (RTC).

\begin{tabular}{llllll}
\hline & & \multicolumn{4}{c}{ Total length } \\
\cline { 3 - 6 } Species & $N$ & Mean & SD & Min & Max \\
\hline BHS & 29 & 210.0 & 23.9 & 161 & 254 \\
FMS & 28 & 252.6 & 79.7 & 152 & 405 \\
WHS & 33 & 260.0 & 41.4 & 180 & 387 \\
Hybrid & 66 & 265.6 & 79.4 & 133 & 403 \\
CKC & 50 & 131.4 & 27.9 & 70 & 175 \\
RTC & 50 & 152.4 & 53.4 & 60 & 270 \\
\hline
\end{tabular}

bluehead suckers, white suckers, and roundtail chub, whereas fin rays had the lowest between-reader $\mathrm{CV}$ for flannelmouth suckers, catostomid hybrids, and creek chub (Table 2). The mean CV in age estimates between readers was generally highest for cleithra and caudal scales but was also high for opercles and pectoral scales.

Agreement between otolith age and ages from other hard structures varied among species and between readers (Table 3 ). When disagreements occurred, they were generally for age-5 and older fish (i.e., based on otolith ages). Exact agreement between fin rays and otolith age estimates averaged $79.9 \%$ for reader 1 and $71.7 \%$ for reader 2 , while age estimates within 1 year averaged $96.1 \%$ for reader 1 and $93.9 \%$ for reader 2 across species. Agreement between fin ray and otolith ages was lowest for creek chub, which was the only species exhibiting a significant difference between fin ray and otolith ages (Table 3 ). Most age estimates from creek chub fin rays were 1-3 years lower than otolith ages for reader 1 and $1-4$ years lower for reader 2 . No distinct patterns of overestimating or underestimating ages with fin rays were apparent for the other species. Opercle and cleithrum age estimates were similar to otolith age estimates for reader 1 , but agreement among these same structures was low for reader 2. Disagreements for reader 1 generally involved an underestimate of otolith age by use of cleithra and an overestimate of otolith age by use of opercles. Reader 2 generally underestimated otolith age by 2-3 years when using cleithra and opercles. Pectoral and caudal scale age estimates were significantly different than otolith ages for all species except creek chub and roundtail chub aged by reader 1 (Table 3). Similar to estimates from other structures, most discrepancies occurred for age-5 and older fish. Pectoral and caudal scale age estimates were significantly different for catostomid hybrids 
TABLE 2.-Precision in age estimates between two readers for otoliths, fin rays, opercles, cleithra, and scales obtained from fish sampled in Muddy Creek, Wyoming, during 20032005. Measures of precision include percent exact agreement (PA-0), percent agreement within 1 year (PA-1), and mean CV (\%). Species include bluehead sucker (BHS), flannelmouth sucker (FMS), white sucker (WHS), hybrid catostomids (hybrid), creek chub (CKC), and roundtail chub (RTC).

\begin{tabular}{|c|c|c|c|}
\hline $\begin{array}{l}\text { Species and } \\
\text { structure }\end{array}$ & $\mathrm{PA}-0$ & PA-1 & $\mathrm{CV}$ \\
\hline \multicolumn{4}{|l|}{ BHS } \\
\hline Otolith & 79.3 & 89.7 & 5.5 \\
\hline Fin ray & 72.4 & 89.7 & 6.7 \\
\hline Opercle & 69.0 & 93.1 & 12.5 \\
\hline Cleithrum & 41.4 & 65.5 & 21.6 \\
\hline Pectoral scale & 41.4 & 82.8 & 15.5 \\
\hline Caudal scale & 31.0 & 82.8 & 30.2 \\
\hline \multicolumn{4}{|l|}{ FMS } \\
\hline Otolith & 71.4 & 85.7 & 6.5 \\
\hline Fin ray & 74.1 & 88.9 & 4.4 \\
\hline Opercle & 25.0 & 64.3 & 17.3 \\
\hline Cleithrum & 32.1 & 64.3 & 20.3 \\
\hline Pectoral scale & 32.1 & 71.4 & 19.9 \\
\hline Caudal scale & 32.1 & 71.4 & 30.0 \\
\hline \multicolumn{4}{|l|}{ WHS } \\
\hline Otolith & 78.8 & 96.9 & 2.5 \\
\hline Fin ray & 60.6 & 93.9 & 3.7 \\
\hline Opercle & 33.3 & 57.6 & 13.1 \\
\hline Cleithrum & 27.3 & 57.6 & 16.2 \\
\hline Pectoral scale & 15.2 & 42.4 & 27.4 \\
\hline Caudal scale & 15.2 & 48.5 & 33.4 \\
\hline \multicolumn{4}{|l|}{ Hybrid } \\
\hline Otolith & 66.2 & 87.7 & 6.1 \\
\hline Fin ray & 75.8 & 89.4 & 4.3 \\
\hline Opercle & 30.3 & 66.7 & 14.9 \\
\hline Cleithrum & 21.2 & 53.0 & 20.5 \\
\hline Pectoral scale & 19.7 & 48.5 & 25.4 \\
\hline Caudal scale & 15.2 & 45.5 & 38.5 \\
\hline \multicolumn{4}{|l|}{ CKC } \\
\hline Otolith & 71.4 & 97.9 & 9.5 \\
\hline Fin ray & 74.0 & 98.0 & 9.3 \\
\hline Opercle & 46.0 & 72.0 & 26.6 \\
\hline Cleithrum & 42.9 & 81.6 & 27.9 \\
\hline Pectoral scale & 36.0 & 74.0 & 27.6 \\
\hline Caudal scale & 40.0 & 80.0 & 33.5 \\
\hline \multicolumn{4}{|l|}{ RTC } \\
\hline Otolith & 95.9 & 95.9 & 1.2 \\
\hline Fin ray & 92.0 & 96.0 & 2.5 \\
\hline Opercle & 46.0 & 76.0 & 22.9 \\
\hline Cleithrum & 36.0 & 80.0 & 23.9 \\
\hline Pectoral scale & 44.0 & 80.0 & 22.9 \\
\hline Caudal scale & 48.0 & 76.0 & 28.8 \\
\hline
\end{tabular}

(reader 1), bluehead suckers (Reader 2), and white suckers (Reader 2). For most species, caudal scale estimates of age were 1 or 2 years greater than those obtained using pectoral scales.

\section{Discussion}

Cleithra and opercles are commonly used to age fishes (e.g., Casselman and Crossman 1986; Sharp and Bernard 1988; DeVries and Frie 1996); however, few studies have been conducted to evaluate the precision among age estimates using these structures. Sharp and
Bernard (1988) examined the precision of cleithra, opercles, and otoliths for aging lake trout Salvelinus namaycush from Alaskan lakes. They found that opercles provided age estimates nearly identical to those from otoliths and suggested that opercles could be used in place of otoliths for many age and growth studies on lake trout. Conversely, cleithrum age estimates for lake trout were substantially lower than otolith ages and exhibited the lowest among- and between-reader precision of any structure examined. Opercle and cleithrum ages of fish in Muddy Creek were generally the same as otolith ages until age 5 (i.e., age 5 based on otoliths). Although otolith, opercle, and cleithrum ages were similar for at least one of the readers, obtaining these structures required lethal sampling. Due to the current status of native fishes in the Colorado River basin (e.g., Bezzerides and Bestgen 2002), sacrificing large numbers of native fishes for age and growth analysis is not recommended and may not be an option in the future. Thus, understanding the accuracy of nonlethal structures for aging native fishes in the UCRB is critical for providing information needed for the management of native fishes.

Fin rays and scales are also commonly used to estimate fish age and do not require sacrifice of fish (e.g., Beamish 1981; DeVries and Frie 1996). Results of studies assessing the accuracy and precision of fin rays are mixed; some studies suggest that fin rays are appropriate for aging some species but not others. For instance, Rossiter et al. (1995) investigated the use of pectoral fin rays for aging lake sturgeon Acipenser fulvescens of known age and found that fin rays provided accurate age estimates. Welch et al. (1993) found that ages from pectoral fin rays were similar to otolith ages (i.e., within 1 year) for striped bass Morone saxatilis from Georgia and South Carolina reservoirs. However, fin rays provided inaccurate and imprecise age estimates for pallid sturgeon Scaphirhynchus albus (Hurley et al. 2004) and white sturgeon A. transmontanus (Rien and Beamesderfer 1994). In our study, age estimates from fin rays were nearly identical to age estimates derived from otoliths for all species and exhibited the lowest between-reader variation among the nonotolith structures. The only exception was creek chub, for which age estimates derived from fin rays and otoliths often differed by more than 2 years.

Scales are one of the most frequently used fish aging structures due to their ease of collection and because fish can be released alive (DeVries and Frie 1996). Because scales are commonly used to age fish, numerous studies have assessed the accuracy and precision of scale age (e.g., Erickson 1983; Boxrucker 1986; Kruse et al. 1993; Long and Fisher 2001). Similar to fin ray estimates of age, accuracy and 
TABLE 3.-Percent agreement (\%) between age estimates obtained using otoliths and those obtained using fin rays, opercles, cleithra, and scales of fish sampled from Muddy Creek, Wyoming, during 2003-2005. Percent agreement between pectoral and caudal scale age estimates is also provided. Exact agreement is given first, and agreement within 1 year is given in parentheses. An asterisk indicates that age estimates for a structure differed from otolith age estimates or that pectoral and caudal scale ages differed (paired $t$-test adjusted for multiple tests: $P<0.0013$ ). Species include bluehead sucker (BHS), flannelmouth sucker (FMS), white sucker (WHS), hybrid catostomids (hybrid), creek chub (CKC), and roundtail chub (RTC).

\begin{tabular}{llccccc}
\hline & \multicolumn{5}{c}{ Structure compared with otolith } & $\begin{array}{c}\text { Pectoral } \\
\text { scale-caudal } \\
\text { Specale agreement }\end{array}$ \\
\cline { 2 - 6 } & \multicolumn{1}{c}{ Fin ray } & Opercle & Cleithrum & Pectoral scale & Caudal scale & \\
BHS & $89.7(100)$ & $82.8(100)$ & $93.1(100)$ & $62.1(79.3)^{*}$ & $62.1(93.1)^{*}$ & $89.7(100)$ \\
FMS & $85.7(92.9)$ & $82.1(100)$ & $85.7(92.8)$ & $46.4(60.7)^{*}$ & $53.6(60.7)^{*}$ & $96.4(100)$ \\
WHS & $72.7(96.9)$ & $93.9(96.9)$ & $78.8(96.9)$ & $45.5(69.7)^{*}$ & $39.4(75.8)^{*}$ & $69.7(96.9)$ \\
Hybrid & $75.4(98.5)$ & $70.8(95.3)$ & $81.5(93.9)$ & $33.9(55.5)^{*}$ & $46.2(66.2)^{*}$ & $59.1(93.9)^{*}$ \\
CKC & $70.0(92.0)^{*}$ & $84.0(100)$ & $89.8(100)$ & $90.0(98.0)$ & $92.0(100)$ & $90.0(98.0)$ \\
RTC & $86.0(96.0)$ & $84.0(96.0)$ & $88.0(96.0)$ & $82.0(94.0)$ & $80.0(96.0)$ & $92.0(100)$ \\
& & & & & \\
BHS & $89.7(100)$ & $72.4(96.5)$ & $27.6(65.5)^{*}$ & $34.5(72.4)^{*}$ & $27.6(72.5)^{*}$ & $27.6(65.6)^{*}$ \\
FMS & $66.7(92.6)$ & $25.0(60.7)$ & $21.4(75.0)$ & $39.3(53.6)^{*}$ & $28.6(49.9)^{*}$ & $39.3(78.6)$ \\
WHS & $60.6(93.9)$ & $30.3(48.5)$ & $18.2(51.6)^{*}$ & $9.1(30.3)^{*}$ & $12.1(36.4)^{*}$ & $24.2(69.7)^{*}$ \\
Hybrid & $76.9(89.2)$ & $29.2(80.1)$ & $24.6(55.4)$ & $12.3(30.8)^{*}$ & $16.9(39.9)^{*}$ & $25.8(68.2)$ \\
CKC & $56.0(92.0)^{*}$ & $52.0(82.0)^{*}$ & $52.0(86.0)^{*}$ & $38.0(82.0)^{*}$ & $50.0(88.0)^{*}$ & $66.0(98.0)$ \\
RTC & $80.0(96.0)$ & $50.0(72.0)^{*}$ & $32.0(76.0)^{*}$ & $40.0(74.0)^{*}$ & $44.0(70.0)^{*}$ & $72.0(92.0)^{*}$ \\
\hline
\end{tabular}

precision of scale ages are highly variable among species. For example, scales provided accurate and precise ages for largemouth bass Micropterus salmoides (Prentice and Whiteside 1974; Long and Fisher 2001), black crappies Pomoxis nigromaculatus (Kruse et al. 1993), and striped bass (Welch et al. 1993). In contrast, many studies have shown that scales tend to underestimate fish age (e.g., Erickson 1983; Schramm and Doerzbacher 1985; Boxrucker 1986; Marwitz and Hubert 1995; Isermann et al. 2003). Scale ages agreed with less than $20 \%$ of the otolith ages for some native and nonnative fishes in Muddy Creek, and many disagreements differed by more than 5 years. In almost all instances, disagreements were due to a lower scale age relative to otolith age. Scale ages from creek chub and roundtail chub were in close agreement with otolith ages for one reader, but most creek chub and roundtail chub were younger than age 5. Similar to results from other studies, we found high agreement between scale age and otolith ages for all fish with an otolith age less than 5 years (e.g., Beamish and McFarlane 1983; Erickson 1983; Boxrucker 1986), suggesting that high agreement for creek chub and roundtail chub was due to the age structure of fish in our sample. Age estimates from pectoral and caudal scales were similar for all species, but caudal scales generally required less processing time and were easier to read given their large size.

Understanding the population dynamics of native and nonnative fishes in the UCRB is important for guiding management and conservation activities. However, obtaining this information is often dependent on accurate and precise estimates of age (e.g., Rien and Beamesderfer 1994; Isermann et al. 2003). Our results suggest that fin rays provide age estimates that are nearly identical to those obtained from otoliths, while age estimates from scales were up to 9 years less-and frequently 5 years less - than otolith ages. Fin rays provided age estimates similar to otolith ages, and collection of fin rays does not require lethal sampling. As such, we recommend that investigators use fin rays for estimating age of native bluehead suckers, flannelmouth suckers, and roundtail chub in the UCRB. Among nonnative fishes in the UCRB, otoliths or fin rays should be used to estimate age, as the sacrifice of these individuals may actually benefit native fishes. However, we recommend use of otoliths for aging creek chub, since fin ray ages were in poor agreement with otolith ages for this species. Although the use of otoliths has been validated for aging of roundtail chub (Brouder 2005), future research is needed to validate the accuracy of using hard structures (particularly otoliths and fin rays) for native catostomids and nonnative species in the UCRB.

\section{Acknowledgments}

We thank R. Beatty, M. Gorges, and K. Lang for assistance in the field. Three anonymous reviewers provided helpful comments on a previous version of the manuscript. Funding was provided by the U.S. Bureau of Land Management, U.S. Bureau of Reclamation, and the Department of Natural Resource Ecology and Management at Iowa State University. The Wyoming Cooperative Fish and Wildlife Research 
Unit is jointly sponsored by the U.S. Geological Survey, University of Wyoming, Wyoming Game and Fish Department, and Wildlife Management Institute. Reference to trade names does not imply endorsement by the U.S. government.

\section{References}

Baxter, G. T., and M. D. Stone. 1995. Fishes of Wyoming. Wyoming Game and Fish Department, Cheyenne.

Beamish, R. J. 1981. Use of fin-ray sections to age walleye pollock, Pacific cod, and albacore, and the importance of this method. Transactions of the American Fisheries Society 110:287-299.

Beamish, R. J., and W. N. McFarlane. 1983. The forgotten requirement for age validation in fisheries biology. Transactions of the American Fisheries Society 112:735-743.

Bezzerides, N., and K. Bestgen. 2002. Status review of roundtail chub Gila robusta, flannelmouth sucker Catostomus latipinnis, and bluehead sucker Catostomus discobolus in the Colorado River basin. Colorado State University, Larval Fish Lab, Contribution 118, Fort Collins.

Bower, M. R. 2005. Distributions and habitat associations of bluehead suckers, flannelmouth suckers, and roundtail chubs in the upper Muddy Creek watershed of southern Carbon County, Wyoming. Master's thesis. University of Wyoming, Laramie.

Boxrucker, J. 1986. A comparison of otolith and scale methods for aging white crappie in Oklahoma. North American Journal of Fisheries Management 6:122-125.

Brouder, M. J. 2005. Age and growth of roundtail chub in the upper Verde River, Arizona. Transactions of the American Fisheries Society 134:866-871.

Campana, S. E., M. C. Annand, and J. I. McMillan. 1995. Graphical and statistical methods for determining the consistency of age determinations. Transactions of the American Fisheries Society 124:131-138.

Casselman, J. M., and E. J. Crossman. 1986. Size, age, and growth of trophy muskellunge and muskellunge-northern pike hybrids - the cleithrum project, 1979-1983. Pages 93-110 in G. E. Hall, editor. Managing muskies: a treatise on the biology and propagation of muskellunge in North America. American Fisheries Society, Special Publication 15, Bethesda, Maryland.

Chen, Y., and H. H. Harvey. 1995. Growth, abundance, and food supply of white sucker. Transactions of the American Fisheries Society 124:262-271.

DeVries, D. R., and R. V. Frie. 1996. Determination of age and growth. Pages 483-512 in B. R. Murphy and D. W. Willis, editors. Fisheries techniques, 2nd edition. American Fisheries Society, Bethesda, Maryland.

Erickson, C. M. 1983. Age determination of Manitoban walleyes using otoliths, dorsal spines, and scales. North American Journal of Fisheries Management 3:176-181.

Hoff, G. R., D. J. Logan, and D. G. Markle. 1997. Otolith morphology and increment validation in young Lost River and shortnose suckers. Transactions of the American Fisheries Society 126:488-494.

Hurley, K. L., R. J. Sheehan, and R. C. Heidinger. 2004. Accuracy and precision of age estimates for pallid sturgeon from pectoral fin rays. North American Journal of Fisheries Management 24:715-718.

Isermann, D. A., J. R. Meerbeek, G. D. Scholten, and D. W. Willis. 2003. Evaluation of three different structures used for walleye age estimation with emphasis on removal and processing times. North American Journal of Fisheries Management 23:625-631.

Kruse, C. G., C. S. Guy, and D. W. Willis. 1993. Comparison of otolith and scale age characteristics for black crappies collected from South Dakota waters. North American Journal of Fisheries Management 13:856-858.

Long, J. M., and W. L. Fisher. 2001. Precision and bias of largemouth, smallmouth, and spotted bass ages estimated from scales, whole otoliths, and sectioned otoliths. North American Journal of Fisheries Management 21:636-645.

Manly, B. F. J., L. L. McDonald, D. L. Thomas, T. L. McDonald, and W. P. Erickson. 2002. Resource section by animals, statistical design and analysis for field studies, 2nd edition. Kluwer, Boston.

Marwitz, T. D., and W. A. Hubert. 1995. Precision of age estimates of Wyoming walleyes from different calcified structures. Prairie Naturalist 27:41-49.

Minckley, W. L., and J. E. Deacon, editors. 1991. Battle against extinction: native fish management in the American West. University of Arizona Press, Tucson.

Moyle, P. B., and R. A. Leidy. 1992. Loss of biodiversity in aquatic ecosystems: evidence from fish faunas. Pages 127-169 in P. L. Fielder and S. K. Jain, editors. Conservation biology: the theory and practice of nature conservation, preservation, and management. Chapman and Hall, New York.

Parrish, D. L., B. Vondracek, and W. J. Eckmayer. 1994. Accuracy and precision of daily age estimates for walleyes from Ohio hatcheries and Lake Erie. Transactions of the American Fisheries Society 123:601-605.

Peterson, M. S., L. C. Nicholson, D. J. Snyder, and G. L. Fulling. 1999. Growth, spawning preparedness, and diet of Cyleptus meridonalis (Catostomidae). Transactions of the American Fisheries Society 128:900-908.

Prentice, J. A., and B. G. Whiteside. 1974. Validation of aging techniques for largemouth bass and channel catfish in central Texas farm ponds. Proceedings of the Annual Conference of the Southeastern Association of Fish and Wildlife Agencies 28(1971):414-428.

Quist, M. C., M. R. Bower, and W. A. Hubert. 2006. Summer food habits and trophic overlap of roundtail chub and creek chub in Muddy Creek, Wyoming. Southwestern Naturalist 51:22-27.

Quist, M. C., and C. S. Guy. 2001. Growth and mortality of prairie stream fishes: relations with fish community and instream habitat characteristics. Ecology of Freshwater Fish 10:88-96.

Rien, T. A., and R. C. Beamesderfer. 1994. Accuracy and precision of white sturgeon age estimates from pectoral fin rays. Transactions of the American Fisheries Society 123:255-265.

Ross, J. R., J. D. Crosby, and J. T. Kosa. 2005. Accuracy and precision of age estimation of crappies. North American Journal of Fisheries Management 25:423-428.

Rossiter, A., D. L. G. Noakes, and F. W. H. Beamish. 1995. Validation of age estimation for the lake sturgeon. 
Transactions of the American Fisheries Society 123: 255-265.

Schneidervin, R. W., and W. A. Hubert. 1986. A rapid technique for otolith removal from salmonids and catostomids. North American Journal of Fisheries Management 6:287.

Schramm, H. L., Jr., and J. F. Doerzbacher. 1985. Use of otoliths to age black crappie from Florida. Proceedings of the Annual Conference of the Southeastern Association of Fish and Wildlife Agencies 36(1982):95-105.

Scoppettone, G. G. 1988. Growth and longevity of the cui-ui and longevity of other catostomids and cyprinids in western North America. Transactions of the American Fisheries Society 117:301-307.

Sharp, D., and D. R. Bernard. 1988. Precision of estimated ages of lake trout from five calcified structures. North American Journal of Fisheries Management 8:367-372.

Taubert, B. D., and J. A. Tranquilli. 1982. Verification of the formation of annuli in otoliths of largemouth bass. Transactions of the American Fisheries Society 111: 531-534.

Vanicek, C. D., and R. H. Kramer. 1969. Life history of the Colorado squawfish, Ptychocheilus lucius, and the Colorado chub, Gila robusta, in the Green River in Dinosaur National Monument, 1964-1966. Transactions of the American Fisheries Society 98:193-208.

Welch, T. J., M. J. Van Den Avyle, R. K. Betsill, and E. M. Driebe. 1993. Precision and relative accuracy of striped bass age estimates from otoliths, scales, and anal fin rays and spines. North American Journal of Fisheries Management 13:616-620.

Williams, J. E., J. E. Johnson, D. A. Hendrickson, S. Contreras-Balderas, J. D. Williams, M. Navarro-Mendoza, D. E. McAllister, and J. E. Deacon. 1989. Fishes of North America: endangered, threatened, or of special concern. Fisheries 14(6):2-20. 